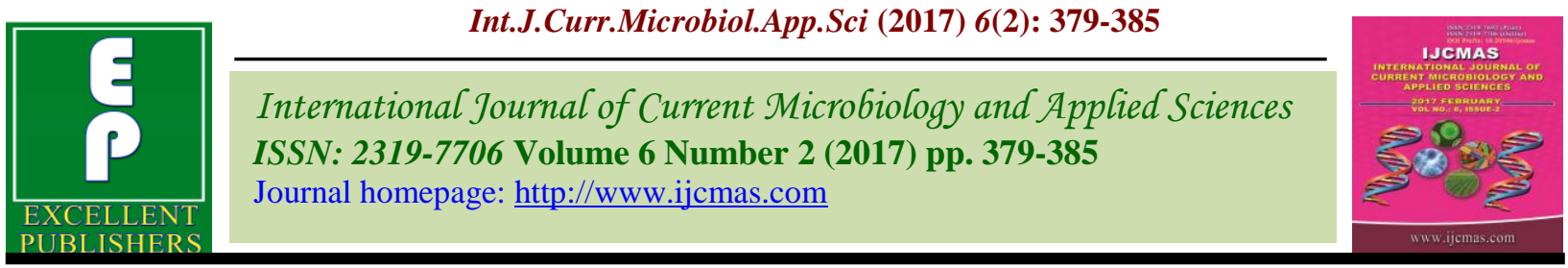

Original Research Article

http://dx.doi.org/10.20546/ijcmas.2017.602.042

\title{
Integrated Nutrient Management (INM) in Sorghum Chickpea Cropping System under Unirrigated Conditions
}

\author{
Seema M. Nemade ${ }^{1 *}$, R.B. Ghorade ${ }^{1}$ and N.B. Mohod $^{2}$ \\ ${ }^{1}$ Sorghun Research Unit, Dr. P.D.K.V., Akola, India \\ ${ }^{2}$ CDF, Dr. P.D.K.V., Akola, India \\ *Corresponding author
}

\section{A B S T R A C T}

To identify an ideal combination of organic and inorganic nutrient sources for getting maximum yield of kharif sorghum and rabi chickpea sequence a field experiment on Integrated Nutrient Management in kharif sorghum chickpea cropping system was

\begin{tabular}{|l|}
\hline Ke y w or d s \\
INM, \\
Sorghum, \\
Chickpea, \\
Cropping \\
Sequence.
\end{tabular}
conducted during kharif season of 2013-2015 at the farm of Sorghum Research Unit (CRS) Dr.PDKV, Akola. The experiment was planned in RBD with the treatments as Nutrient management treatments - 09 (Kharif-Sorghum) T1-100\% RDN through inorganic fertilizer, T2-50\% RDN through inorganic fertilizer+50\% RDN through FYM, T3-75\% RDN through inorganic fertilizer+25\% RDN through FYM, T4-50\% RDN through inorganic fertilizer+50\% RDN through vermicompost, N5:75\% RDN through inorganic fertilizer+25\% RDN through vermicompost, T6-50\% RDN through inorganic fertilizer+25\% RDN through FYM+25\% RDN through vermicompost, T7-75\% RDN through inorganic fertilizer+25\% RDN through FYM+seed treatment with microbial fertilizers PSB+Azospirillum, T8-75\% RDN through inorganic fertilizer $+25 \%$ RDN through vermicompost+seed treatment with microbial fertilizers PSB+ Azospirillum, T9$75 \%$ RDN through inorganic fertilizer+seed treatment with microbial fertilizers PSB+Azospirillum. In rabi chickpea was gown on the same randomization without application of fertilizers. It can be concluded from the three years experiment that the integrated treatments are superior to inorganic treatment. Application of $75 \%$ RDN through inorganic fertilizer+25\% RDN through FYM + seed treatment with PSB + Azospirillum to kharif sorghum and growing rabi chickpea without recommended dose of fertilizer is the superior treatment for getting maximum growth and yield attributes and yield of individual crop as well as of the system.

\section{Introduction}

Improving and maintaining soil quality for enhancing and sustaining agricultural production is of utmost importance for India's food and nutritional security. INM has multifaceted potential for the improvement of plant performance and resource efficiency while also enabling the protection of the environment and resource quality. A comprehensive literature search revealed that INM enhances crop yields by $8-150 \%$ compared with conventional practices, increases water-use efficiency, and the economic returns to farmers, while improving grain quality and soil health and sustainability (Wei Wua and Baoluo Ma, 2015). It is well known that the organic sources cannot meet 
the total nutrients need to modern agriculture, integrated use of nutrients seems to be more appropriate. Incorporation of organic sources and later on its decomposition determines the availability of the nutrients. Organic sources of nutrients applied to the preceding crop benefits the succeeding crop to a great extent (Hedge and Dwivedi, 1992). Therefore, the present study was undertaken with a view to find out the efficient combination of organic and inorganic fertilizers under sorghumchickpea cropping sequence under rainfed conditions.

\section{Materials and Methods}

A field experiment was conducted at Sorghum Research Unit Dr. Panjabrao Deshmukh Kruhi Vidhyapeeth, Akola, Maharashtra, during the rainy (kharif) and winter (rabi) seasons of 2013-2015. Nine Nutrient application treatments (INM) were assessed during Kharif for Sorghum and in rabi chickpea was grown on same site same randomization without any RDF in three replication in $\mathrm{RBD}$ on clayey soil, having $\mathrm{pH}$ 8.32 and electrical conductivity $0.28 \mathrm{dS} / \mathrm{m}$. It was medium in organic carbon $(0.53 \%)$, low in available nitrogen (232 kg/ha), low in available phosphorus (20.34 kg/ha) and high in available potassium (365 kg/ha). The experiment was laid out in randomized block design and nine nutrient application treatments (INM) were assessed during Kharif for Sorghum and in rabi chickpea was grown without any RDF in three replication (Table 1) Recommended doses of inorganic fertilizers consisting of $80 \mathrm{~kg} \mathrm{~N}$ and $40 \mathrm{~kg}$ each of $\mathrm{P}_{2} \mathrm{O}_{5}$ and $\mathrm{K}_{2} \mathrm{O} /$ ha were applied to sorghum only and rabi Chickpea was grown on residual soil nutrients. For sorghum $\mathrm{N}$ was applied in 2 splits, half at sowing along with entire quantity of $\mathrm{P}_{2} \mathrm{O}_{5}$ and $\mathrm{K}_{2} \mathrm{O}$ and remaining $\mathrm{N}$ was applied 30 days after sowing. Nitrogen, phosphorus and potassium were applied through urea, single superphosphate and muriate of potash, respectively. The FYM and vermicompost were applied based on the nitrogen equivalent basis and nutrient requirement of sorghum and biofertilizers used in the form of seed inoculation were Azospirillum and phosphatesolubilizing bacteria. Sorghum (CSH-14) and chickpea (JAKI- 9218) were sown using seed rates of 7.5-10 kg ha-1 and 75-85 $\mathrm{kg} \mathrm{ha}^{-1}$ with a spacing of $45 \mathrm{~cm} \times 15 \mathrm{~cm}$ and $30 \mathrm{~cm} \times 10$ $\mathrm{cm}$ for sorghum and chickpea respectively. Sorghum was sown in second fortnight of July and harvested during 1st week of November. To study the residual effect of INMS treatments chickpea was sown on same site without changing the randomization in 2nd week of November and harvested in 1st week of March during each year of experimentation. The crop sequence received total rainfall of $946.4 \mathrm{~mm}$ in 2013-14, 623.6 $\mathrm{mm}$ in 2014-15 and $796.5 \mathrm{~mm}$ in 2015-16 during the crop growth periods. The data on growth and yield attributes, grain and fodder yields of sorghum and chickpea were recorded. Representative soil samples were drawn before start of the experiment and also at each harvest of the sequence. Representative plant and grain samples were also drawn from each harvest of the sequence. The data was analyzed statistically as per Panse and Sukhatme (1967).

\section{Results and Discussion}

The residual effect of treatments with combination of organic and inorganic manures significantly influenced the plant height of sorghum. The plant height was significantly maximum with the application of $75 \%$ RDN through inorganic fertilizer $+25 \%$ RDN through FYM+ seed treatment with microbial fertilizers PSB+ Azospirillum however it was at par with $75 \%$ RDN through inorganic fertilizer+25\% RDN through vermicompost+ seed treatment with microbial fertilizers PSB+Azospirillum during the years 
as well as in pooled mean. Better nutrient availability might have resulted in greater plant height. Yield attributing characters as Panicle length $(\mathrm{cm})$, Grain wt per panicle $(\mathrm{g})$ and Grain No/panicle of kharif sorghum was significantly maximum with the application of $75 \%$ RDN through inorganic fertilizer+25\% RDN through FYM+ seed treatment with microbial fertilizers PSB+ Azospirillum however it was at par with $75 \%$ RDN through inorganic fertilizer+25\% RDN through vermicompost+ seed treatment with microbial fertilizers PSB+Azospirillum during the years as well as in pooled mean. Integrated nutrient management treatments had recorded better crop growth and yield attributing characters than only inorganic fertilizer application owing to better soil conditions and moisture storage in soil. The yield attributing characters were resulted in to higher yield of grain as well as fodder of sorghum and the application of $75 \%$ RDN through inorganic fertilizer+25\% RDN through FYM+ seed treatment with microbial fertilizers PSB+ Azospirillum recorded significantly higher grain as well as fodder yield however it was at par with $75 \%$ RDN through inorganic fertilizer+25\% RDN through vermicompost+ seed treatment with microbial fertilizers PSB+ Azospirillum during the years as well as in pooled mean. The lowest grain and fodder yield was recorded with the application of $75 \%$ RDN through inorganic fertilizer+seed treatment with microbial fertilizers PSB+ Azospirillum. The response to FYM application may be attributed to the better nutrient availability and its favourable effect on soil physical and biological properties, resulting in increased growth and yield attributes and finally higher yields.

Chickpea grown after harvest of sorghum responded favorably to the residual effect of INM treatments applied to the preceding crop sorghum. Number of pods/plant, grain yield and dry fodder yield of chickpea was significantly maximum with the application of $75 \%$ RDN through inorganic fertilizer $+25 \%$ RDN through FYM+ seed treatment with microbial fertilizers PSB+ Azospirillum however it was at par with $75 \%$ RDN through inorganic fertilizer+25\% RDN through vermicompost+ seed treatment with microbial fertilizers PSB+Azospirillum during the years as well as in pooled mean. This indicated that the residual nutrients were adequate. Inclusion of legumes in cropping systems for green-manuring, fodder or grain purposes proved an as sured agro-technique to improve nutrient-use efficiency especially that of $\mathrm{N}$ (Yadav et al., 1996).

Table.1 Treatment details (Kharif- Sorghum)

\begin{tabular}{|c|c|c|}
\hline T1 & : & $100 \%$ RDN through inorganic fertilizer \\
\hline $\mathbf{T 2}$ & $:$ & $50 \%$ RDN through inorganic fertilizer+50\% RDN through FYM \\
\hline T3 & : & $75 \%$ RDN through inorganic fertilizer+25\% RDN through FYM \\
\hline T4 & : & $50 \%$ RDN through inorganic fertilizer+50\% RDN through vermicompost \\
\hline N5 & : & $75 \%$ RDN through inorganic fertilizer+25\% RDN through vermicompost \\
\hline T6 & : & $50 \%$ RDN through inorganic fertilizer+25\% RDN through FYM+25\% RDN through \\
\hline T7 & : & $\begin{array}{l}\text { 75\% RDN through inorganic fertilizer+25\% RDN through FYM+ seed treatment with microbial } \\
\text { fertilizers PSB+Azospirillum }\end{array}$ \\
\hline T8 & & $\begin{array}{l}75 \% \text { RDN through inorganic fertilizer+25\% RDN through vermicompost+ seed treatment with } \\
\text { microbial fertilizers PSB }+ \text { Azospirillum }\end{array}$ \\
\hline T9 & $:$ & $75 \%$ RDN through inorganic fertilizer+seed treatment with microbial fertilizers \\
\hline
\end{tabular}


Table.2 Plant height $(\mathrm{cm})$ and panicle length $(\mathrm{cm})$,grain wt per panicle $(\mathrm{g})$,grain no per panicle, grain yield and dry fodder yield $(\mathrm{q} / \mathrm{ha})$ and sorghum equivalent yield (q/ha) of kharif sorghum as influenced by different treatments

\begin{tabular}{|c|c|c|c|c|c|c|c|c|c|c|c|c|c|c|c|c|c|c|c|c|c|c|}
\hline \multirow{2}{*}{ Treatment details } & \multicolumn{4}{|c|}{ Plant height (cm) } & \multicolumn{3}{|c|}{ Panicle length (cm) } & \multicolumn{3}{|c|}{ Grain wt per panicle } & \multicolumn{3}{|c|}{ Grain No/panicle } & \multicolumn{4}{|c|}{ Grain yield $(\mathbf{q} / \mathbf{h a})$} & \multicolumn{4}{|c|}{ Dry fodder yield (q/ ha) } & \multirow{2}{*}{$\begin{array}{l}\text { Sorgh } \\
\text { um } \\
\text { Equiv } \\
\text { alent } \\
\text { Yield } \\
\text { (q/ha) }\end{array}$} \\
\hline & 2013 & 2014 & 2015 & Pooled & 2014 & 2015 & Pooled & 2014 & 2015 & Pooled & 2014 & 2015 & Pooled & 2013 & 2014 & 2015 & Pooled & 2013 & 2014 & 2015 & Pooled & \\
\hline N1:100\% RDN(IF) & 219.60 & 195.67 & 203.00 & 206.09 & 25.16 & 25.30 & 25.23 & 31.60 & 35.14 & 33.37 & 1994 & 2249 & 2122 & 27.39 & 30.14 & 23.10 & 26.88 & 136.93 & 99.73 & 103.63 & 113.43 & 64.31 \\
\hline $\begin{array}{l}\text { N2:50\% RDN(IF) }+50 \% \text { RDN } \\
\text { FYM }\end{array}$ & 197.61 & 206.00 & 213.33 & 205.65 & 26.77 & 26.90 & 26.84 & 39.58 & 43.12 & 41.35 & 2105 & 2360 & 2233 & 21.69 & 34.03 & 26.04 & 27.25 & 114.94 & 112.97 & 113.64 & 113.85 & 71.31 \\
\hline $\begin{array}{l}\text { N3:75\% RDN } \\
\text { RDN FYM }\end{array}$ & 189.78 & 218.33 & 225.67 & 211.26 & 28.14 & 28.28 & 28.21 & 41.21 & 44.75 & 42.98 & 2068 & 2323 & 2196 & 20.21 & 35.74 & 27.33 & 27.76 & 100.45 & 122.24 & 120.64 & 114.44 & 67.86 \\
\hline $\begin{array}{l}\text { N4:50\% RDN (IF)+50\% RDN } \\
\text { VC }\end{array}$ & 215.18 & 199.33 & 206.67 & 207.06 & 26.68 & 26.82 & 26.75 & 40.54 & 44.08 & 42.31 & 2093 & 2488 & 2291 & 31.66 & 31.64 & 24.23 & 29.18 & 163.11 & 105.94 & 108.33 & 125.79 & 67.24 \\
\hline $\begin{array}{l}\text { N5:75\% RDN(IF) }+25 \% \text { RDN } \\
\text { VC }\end{array}$ & 211.44 & 182.33 & 189.67 & 194.48 & 27.14 & 27.28 & 27.21 & 41.34 & 44.87 & 43.105 & 2058 & 2313 & 2185 & 27.01 & 35.36 & 27.04 & 29.80 & 132.51 & 119.97 & 118.93 & 123.80 & 69.05 \\
\hline $\begin{array}{l}\text { N6:50\% RDN(IF) }+25 \% \text { RDN } \\
\text { FYM+25\% RDN VC }\end{array}$ & 193.42 & 208.67 & 216.00 & 206.03 & 27.01 & 27.15 & 27.08 & 40.40 & 43.93 & 42.165 & 2120 & 2375 & 2248 & 19.54 & 32.78 & 25.09 & 25.80 & 105.09 & 116.58 & 116.37 & 112.68 & 64.54 \\
\hline $\begin{array}{l}\text { N7:75\% RDN(IF)+25\% RDN } \\
\text { FYM+ST(PSB+ Azspirillum) }\end{array}$ & 210.75 & 225.67 & 233.00 & 223.14 & 28.69 & 29.16 & 28.93 & 45.04 & 48.58 & 46.81 & 2233 & 2387 & 2310 & 26.31 & 38.86 & 29.69 & 31.62 & 129.42 & 134.98 & 130.27 & 131.56 & 79.99 \\
\hline $\begin{array}{l}\text { N8:75\% RDN(IF) +25\% RDN } \\
\text { ST (PSB+Azospirillum) }\end{array}$ & 180.95 & 225.33 & 232.67 & 212.98 & 28.59 & 28.72 & 28.66 & 43.39 & 46.93 & 45.16 & 2132 & 2348 & 2240 & 27.49 & 37.37 & 28.56 & 31.14 & 124.95 & 124.85 & 122.62 & 124.14 & 75.59 \\
\hline $\begin{array}{l}\text { N9:75\% RDN(IF) + ST (PSB+ } \\
\text { Azospirillum) }\end{array}$ & 179.85 & 196.00 & 203.33 & 193.06 & 25.46 & 25.60 & 25.53 & 35.75 & 39.28 & 37.515 & 2142 & 2397 & 2270 & 19.08 & 31.04 & 23.77 & 24.63 & 97.18 & 103.92 & 106.80 & 102.63 & 55.73 \\
\hline $\mathrm{SE}(\mathrm{m}) \pm$ & 15.72 & 11.46 & 8.88 & 2.46 & 0.15 & 0.09 & 0.02 & 0.90 & 0.78 & 0.48 & 32 & 35 & 35 & 1.94 & 1.18 & 0.90 & 0.48 & 12.27 & 5.05 & 8.38 & 1.02 & 2.04 \\
\hline CD P $=0.05$ & NS & 24.28 & 25.12 & 6.97 & 0.31 & 0.27 & 0.07 & 1.90 & 2.22 & 1.36 & 68 & 98 & 99 & 5.82 & 2.50 & 2.56 & 1.37 & 36.80 & 10.70 & 23.70 & 2.87 & 5.78 \\
\hline
\end{tabular}

RDN: Recommended dose of nitrogen, FYM: Farm yard manure, VC: Vermicompost, ST:Seed Treatment, IF:Inorganic fertilizer 
Table.3 No. of pods /plant, grain yield and dry fodder yield (q/ ha) of rabi chickpea as influenced by different treatments

\begin{tabular}{|c|c|c|c|c|c|c|c|c|c|c|c|c|}
\hline \multirow{2}{*}{ Treatment details } & \multicolumn{4}{|c|}{ No. of Pods /plant } & \multicolumn{4}{|c|}{ Grain yield (q/ha) } & \multicolumn{4}{|c|}{ Dry fodder yield (q/ ha) } \\
\hline & 2013 & 2014 & 2015 & Pooled & 2013 & 2014 & 2015 & Pooled & 2013 & 2014 & 2015 & Pooled \\
\hline N1:100\% RDN(IF) & 24.41 & 24.41 & 18.77 & 22.53 & 12.32 & 11.70 & 9.17 & 11.23 & 15.97 & 19.09 & 16.64 & 17.23 \\
\hline N2:50\% RDN(IF) +50\% RDN FYM & 37.07 & 25.30 & 23.59 & 28.65 & 15.78 & 12.51 & 10.86 & 13.22 & 22.02 & 16.98 & 17.25 & 18.75 \\
\hline N3:75\% RDN (IF) +25\% RDN FYM & 25.30 & 27.63 & 21.22 & 24.72 & 11.07 & 14.14 & 10.38 & 12.03 & 17.60 & 20.64 & 18.22 & 18.82 \\
\hline N4:50\% RDN (IF)+50\% RDN VC & 36.91 & 23.63 & 22.42 & 27.65 & 14.93 & 9.95 & 8.87 & 11.42 & 21.60 & 16.07 & 16.51 & 18.06 \\
\hline N5:75\% RDN(IF) +25\% RDN VC & 25.63 & 31.81 & 24.11 & 27.18 & 10.57 & 14.08 & 10.17 & 11.77 & 21.41 & 19.40 & 18.66 & 19.82 \\
\hline $\begin{array}{l}\text { N6:50\% RDN(IF) }+25 \% \text { RDN FYM+25\% } \\
\text { RDN VC }\end{array}$ & 31.81 & 24.63 & 21.39 & 25.94 & 14.76 & 10.45 & 9.15 & 11.62 & 21.26 & 16.07 & 16.39 & 17.91 \\
\hline $\begin{array}{l}\text { N7:75\%RDN(IF)+25\%RDNFYM+SD(PS } \\
\text { B+ Azspirillum) }\end{array}$ & 24.63 & 37.07 & 27.29 & 29.66 & 14.70 & 15.16 & 12.27 & 14.21 & 19.71 & 22.98 & 20.48 & 21.06 \\
\hline $\begin{array}{l}\text { N8: } 75 \% \text { RDN(IF) }+25 \% \text { RDN SD (PSB+ } \\
\text { Azospirillum) }\end{array}$ & 27.63 & 36.91 & 28.18 & 30.91 & 13.13 & 14.31 & 11.18 & 13.04 & 18.43 & 20.79 & 18.60 & 19.27 \\
\hline $\begin{array}{l}\text { N9:75\% RDN(IF) } \\
\text { Azospirillum) }\end{array}$ & 23.63 & 24.41 & 18.51 & 22.18 & 10.42 & 9.8 & 7.27 & 9.33 & 16.69 & 16.03 & 14.84 & 15.85 \\
\hline $\mathrm{SE}(\mathrm{m}) \pm$ & 3.62 & 3.62 & 1.54 & 1.60 & 0.47 & 0.47 & 0.55 & 0.58 & 1.15 & 1.15 & 0.69 & 0.63 \\
\hline CD P $=0.05$ & 10.85 & 7.68 & 4.35 & 4.52 & 1.40 & 0.99 & 1.55 & 1.65 & 3.15 & 2.44 & 1.94 & 1.77 \\
\hline
\end{tabular}


Significantly maximum sorghum equivalent $\operatorname{yield}(\mathrm{q} / \mathrm{ha})$ was recorded with the application of $75 \%$ RDN through inorganic fertilizer+25\% RDN through FYM+ seed treatment with microbial fertilizers PSB+ Azospirillum however it was at par with $75 \%$ RDN through inorganic fertilizer+25\% RDN through vermicompost+ seed treatment with microbial fertilizers PSB+ Azospirillum during the years as well as in pooled mean. The lowest sorghum equivalent yield was recorded with the application of $75 \% \mathrm{RDN}$ through inorganic fertilizer + seed treatment with microbial fertilizers PSB+ Azospirillum.

The sustained availability of nutrient may be attributed to the reason that FYM acts as nutrients reservoir and release major and minor nutrients slowly. The superiority of organic manure is also because of its beneficial effect on soil physical condition apart from acting as nutrient source (Laddha, 1993). Gawai and Pawar (2007) reported similar results of recording higher values for number of pods, grain weight and total dry matter per plant and 1000 seed weight. Results of long-tern fertilizer experiments further supported the beneficial role of farmyard manure in enhancing apparent use efticiency of fertilizer NPK, add maintaining yield stability in multiple cropping systems (Nambiar, 1994).

Dubey et al., (1997) also reported that organic manure application in conjunction with lower doses of $\mathrm{N}, \mathrm{P}$ and $\mathrm{K}$ resulted in higher grain yield in important cropping systems. Singh et al., (1981) opined that the organic manures like FYM increased the adsorptive power of soil for cations and anions particularly phosphates and nitrates and these were released slowly for the benefit of crops during entire crop growth period leading to higher yields The results clearly showed the combined application of manures, fertilizers and biofertilizers produced higher yield than when inorganic fertilizers applied alone.
Data in consideration with growth and yield, it is revealed that, the use of farm yard manure to compensate $25 \%$ nitrogen dose and biofertilizers in combination with 75 per cent recommended dose for sorghum crop in sorghum- chickpea cropping sequence is the most appropriate source for optimum nutrient balance in said sequence. Thus, it can be concluded that, integration of inorganic fertilizers (75 per cent RDF) and organic manures (FYM) at 2.5 ton per ha and seed treatment with biofertilizers to sorghum crop followed by chickpea without application of recommended dose is the best proposition to achieve the high productivity of sorghum and chickpea sequence. Similar results were obtained by Gawai and Pawar (2006), Sarangmath et al., (1994).

\section{References}

Dubey, S.K., Sharmar, S. and Vishwakarma, S.K. 1997. Integrated nutrient management for sustainable productivity of important cropping systemsin Madhya Pradesh. Indian $J$ Agron., 42: 13-17.

Gawai, P.P. and Pawar, V.S. 2006. Integrated nutrient management in sorghum (Sorghum bicolor)-chickpea (Cicer arietinum) cropping sequence under irrigated conditions. Indian $J$. Agronomy, 51(1): 17-20.

Hegde, D.M. and Dwivedi, B.S. 1992. Nutrient management in rice-wheat cropping system in India. Fertilizer News, 37: 27-41.

Laddha, K.C. 1993. 'Interactive effect of tillage and phosphate fertilization in conjuction with FYM on soil physical parameters and yield of sorghum inlercropped with greengram under dry land'. Ph D thesis, Rajasthall Agriculture University, Udaipur.

Nambiar, K.K.M. 1994. Soil Fertility and Crop Productivity under Long-term, 
Fertilizer Use in India. Indian Council of Agricultural Research, New Delhi.

Panse, V.G. and Sukhatme, P.V. 1967. Statistical Methods for Agricultural Workers, ICAR, New Delhi, pp. 359.

Sarangamath, P.A., Itnal, C.J., Basavaraj, P.K., Bidari, B.I., Lingaraju, B.S. 1994. Response of rabi sorghum to application of farm yard manure and fertilizers. Karnataka J. Agri. Sci., 7(3): 349-351.

Singh, B.P., Chahal, R.S. and Ghosh, A.B. 1981. Fertility management through organic and inorganic fertilizers in bajra-whcat crop sequence. Fertiliser News, 26(8): 16-19.

Wei Wua and Baoluo Ma. 2015. Integrated nutrient management (INM) for sustaining crop productivity and reducing environmental impact: A review. Sci. Total Environ., 512513(15): 415-427.

Yadav, R.L., Dwivedi, B.S., Gangwar, K.S. and Kamta Prasad. 1996. Overview and prospects for enhancing residual benefits of legumes in rice-wheat cropping systems in India'. Paper presented at legume workshop, held during 27-29 August 1996 at International Crops Research Institute for the Semi-Arid Tropics, Patancheru, Hyderabad, India.

\section{How to cite this article:}

Seema M. Nemade, R.B. Ghorade and Mohod, N.B. 2017. Integrated Nutrient Management (INM) in Sorghum Chickpea Cropping System under Unirrigated Conditions. Int.J.Curr.Microbiol.App.Sci. 6(2): 379-385. doi: http://dx.doi.org/10.20546/ijcmas.2017.602.042 